\title{
ECONOMIC INCARCERATION
}

\section{Bridget McCormack*}

The adjudication of minor crimes has long proven onerous for defendants. Recently, however, many American jurisdictions bave supplemented the "process" burdens associated with minor crimes. They have done so by requiring misdemeanor defendants to pay much of the significant economic costs associated with the adjudication process, in addition to significant fines. These include, for example, the costs associated with electronic tethers, "reimbursement" fees to police and prosecutors, and participation in court-ordered programs, among others. Assessed in so many different forms, such costs are not fully appreciated by misdemeanor defendants until they face the burden of trying to pay them. Unfortunately, courts have not made any attempt to accommodate defendants' ability to pay, instead often requiring a defendant immediately to pay a sum that is simply impossible given the defendant's income. These burdens are being borne by a segment of the population least likely to be able to bear them, as a majority of the misdemeanants are indigent.

There are significant social costs associated with this new trend in minor crime adjudication. First, there are social-welfare losses resulting from lost wages and income tax revenues, the increased costs of new prosecutions and jail sentences imposed when costs, fees, and other economic sanctions are not paid, and indirectly the increased costs of public assistance for low-income defendants who lose their jobs as a result of contempt orders for their failure to pay on time. These costs have to be measured against any increase in county revenues from economic sanctions. But there is a larger problem as well: Courts' recent willingness to impose greater process-oriented economic sanctions for minor crimes cannot be easily justified by any of the traditional theories of criminal punishment. That difficulty, coupled with the questionable social balance sheet resulting from the increased sanctions, casts serious doubt on this emergent trend.

Le jugement de crimes mineurs s'avère onéreux pour les défendeurs depuis longtemps. Récemment, cependant, dans plusieurs territoires américains, on a ajouté aux fardeaux «liés au processus» associés aux crimes mineurs. On a fait cela en exigeant que les défendeurs accusés de méfaits mineurs paient une bonne part des coûts économiques importants associés aux processus de jugement, en plus d'amendes considérables, y compris, par exemple, les coûts associés aux laisses électroniques, des frais de «remboursement» à la police et aux

\footnotetext{
Associate Dean for Clinical Affairs and Clinical Professor of Law, University of Michigan Law School. This paper was presented at the University of Windsor Law Faculty in the 2006-07 Distinguished Access to Justice Lecture. I would like to thank the participants for their helpful questions and comments, and Professor William Conklin in particular for inviting me to participate. I would also like to thank Dan Clark for his excellent research assistance, and Kim Thomas, Juliet Brodie, Paul Reingold and especially Steven Croley for their helpful comments and ideas.
} 
procureurs et la participation à des programmes mandatés par la cour, entre autres. Puisqu'ils sont établis de tant de façons différentes, les défendeurs en question ne se rendent pas compte tout à fait de ces coûts jusqu'à ce qu'ils se trouvent devant le fardeau d'essayer de les payer. Malheureusement, les cours n'ont fait aucun effort pour tenir compte de la capacité des défendeurs de payer; plutôt, ils exigent souvent que le défendeur paie immédiatement une somme qu'il lui est impossible de payer compte tenu de son revenu. Ces fardeaux tombent sur les épaules d'une partie de la population qui est la moins apte à pouvoir les supporter, puisqu'une majorité des malfaiteurs sont indigents.

Ily a des coûts sociaux importants associés à cette nouvelle tendance pour le jugement de crimes mineurs. D'abord, il y a les pertes en bienêtre social causées par la perte de salaires et de revenus d'impôts, les coûts additionnels de nouvelles poursuites et de peines d'emprisonnement imposées lorsque les coûts, les frais et les autres sanctions économiques ne sont pas payés, et, indirectement, l'augmentation des coûts d'assistance publique pour les défendeurs à faible revenu qui perdent leur emploi suite à une ordonnance d'outrage au tribunal parce qu'ils n'ont pas payé à temps. Il faut mesurer ces coûts en comparaison avec les augmentations de revenus gouvernementaux provenant de sanctions économiques. Mais ily a aussi un plus grand problème: L'empressement récent des cours à imposer des sanctions économiques plus considérables liés au processus pour des crimes mineurs ne peut pas être facilement justifié par n'importe quelle des théories traditionnelles de punition criminelle. Cette difficulté, associée au bilan social contestable dî aux sanctions augmentées, fait planer un doute sérieux sur cette nouvelle tendance.

\section{INTRODUCTION}

The topic of criminal punishment has been thoroughly investigated. The literature on this subject is robust, and the topic is still alive in the academies. Law students encounter it during their first weeks of criminal law, as the justifications for punishment are the background against which the rest of the material is evaluated. ${ }^{1}$ Scholars grapple with its modern implications. ${ }^{2}$ And it continues to animate policy debates as well, most recently in the context of

1 See e.g., Joshua Dressler, Cases and Materials on Criminal Law, 3d.ed. (West Publishing Company, 2003) at 30-62.

2 The contemporary debate is most robust in the death penalty context. Indeed, Cass R. Sunstein and Adrian Vermeule have recently enlivened the deterrence debate surrounding capital punishment, arguing that in some regions capital punishment might deter eighteen murders for every single execution. See "Is Capital Punishment Morally Required? Acts, Omission, and Life-Life Tradeoffs" (2005) 58 Stan. L. Rev. 703. Other scholars disagree with Sunstein and Vermeule's conclusions. See e.g. John Donohue and Justin Wolfers, "Uses and Abuses of Empirical Evidence in the Death Penalty Debate" (2006) 58 Stan. L. Rev. 791 at 794; Jeffrey Fagan et al., "Capital Punishment and Capital Murder: Market Share and the Deterrent Effects of the Death Penalty” (2006) 84 Tex. L. Rev. 1803 at 1806. 
drug sentencing ${ }^{3}$ and, most animatedly perhaps, the death penalty. ${ }^{4}$

Yet one aspect of the subject - the punishment of minor crimes - remains understudied. That is, the examination of punishment for minor crimes has been considered largely only by implication, as if the general analysis might apply, on some smaller scale. But any such implication is misguided, or so this essay will argue, for the punishment of minor crimes can be qualitatively as well as quantitatively different. At the least, as legislatures and courts show new readiness to increase the penalties for minor crimes, often with little regard for the defendant's ability to bear them, the ramifications of the practice require more attention.

This topic has not been forever overlooked. In 1979, Malcolm Feeley published his classic study of the lower criminal courts, The Process Is the Punishment. ${ }^{5}$ Although undertaken by a non-lawyer and limited to New Haven, Connecticut, this book remains the most thorough study available on the topic of punishment for minor crimes. Feeley exposed one central truth pertaining to the vast majority of people prosecuted for minor crimes: regardless of the circumstances of the particular case, most of the punishment received by most criminal defendants was administered before their case was resolved. That is to say, punishment in the majority of cases came in the form of burdens incident to repeated court appearances, as opposed to ex post sentences. As Feeley's title suggests, for most people on the misdemeanor docket a quarter century ago, the process itself was the punishment.

And so it is today. The very process of criminal adjudication continues to be onerous in minor crime prosecutions, especially but not only in jurisdictions encompassing large cities. It is often still true, for example, that the night spent in jail before a defendant's arraignment will likely be the only jail time resulting from the case. In large urban jurisdictions, it is also still true that because a great number of misdemeanor cases are eventually dismissed or resolved without formal sanction, defendants' repeated court appearances will likely be their only contact with the court. ${ }^{6}$ As Feeley demonstrated,

3 See e.g. the Drug Policy Alliance's website capturing the debate, online: Drug Policy Alliance <http://www.drugpolicy.org/drugwar/mandatorymin/>; Real Time with Bill Maher on the "Stupid" Drug War, online: YouTube <http://www.youtube.com/watch?v=RGyq8FwV6a0>; Derrick Z. Jackson, "The Politics of Drug Sentencing” The Boston Globe (28 February 2007).

4 The American Civil Liberties Union's Capital Punishment Project reports that "seven statesColorado, Connecticut, Maryland, Montana, Nebraska, New Jersey and New Mexico have dealt with or will deal with the death penalty debate" in the first quarter of 2007 . According to the ACLU "many of these decisions were lost by one vote. Just one vote in these forums would have advanced the demise of the death penalty not only in those states but in the country", online: American Civil Liberties Union < http:/ /www.aclu.org/capital/29191 res20070326.html>. See also "Prosecutors and the Death Penalty" The Nation (29 March 2007).

5 Malcolm M. Feeley, The Process is the Punishment: Handling Cases in a Lower Criminal Court, (New York: Russell Sage Foundation, 1979).

6 Ibid. By way of example, in 2006 in New York County, New York, 63,860 misdemeanors were arraigned. Of those, 13,312 , or $20.8 \%$, were dismissed, and 11,434 , or $17.9 \%$, were adjourned in contemplation of dismissal, which meant they were dismissed after some waiting period. The citywide dismissal rate was slightly lower: in 2006 throughout the City of New York, 238,665 misdemeanors were arraigned. Of those, 29,735 , or $12.5 \%$, were dismissed, and 48,931 , or $20.5 \%$, were adjourned in contemplation of dismissal. March 28, 2007 interview of Judge Robert Mandelbaum of the New York County Criminal Court, interview notes on file with author. 
however, those repeated court appearances often result in heavy burdens in the form of lost wages, hardship and expense in finding childcare, and termination from a job.

Of course, if legislatures and courts intend a system in which the very process of adjudication constituted the punishment for some categories of minor crime, such a result might be understandable and even justifiable. In fact, some data suggests that almost all the crime control benefits in the enforcement of minor crimes come from the arrest, and that subsequent sanctions flowing from conviction add very little. ${ }^{7}$ Thus, in today's legal system, where even minor convictions carry serious collateral consequences, ${ }^{8}$ legislatures and courts might welcome practices for which the process was the punishment, at least so long as sufficient safeguards ensured that those never convicted did not lose their jobs, subsidized housing, or immigration status. Yet no legislature or court has explicitly espoused such a policy, nor has there been any serious analysis of the question.

There is reason to worry. For one thing, in practice, punishment exacted through the process often proves extremely onerous and can therefore seem highly illegitimate to defendants ensnared in misdemeanor adjudication, especially but by no means only to those never convicted. The burdens incurred during frequent trips to court before the resolution of a case, especially given the inflexibility of courts in scheduling matters, certainly constitute grossly disproportionate process-punishment relative to non-minor charges. The night a defendant spends in jail awaiting arraignment, for instance, when a summons to appear could have just as easily been issued, might well be viewed as excessive punishment for many offenses on the misdemeanor docket.

But observers, not only participants, should reasonably question recent practices. Today, a trend in minor crime adjudication towards steeper processoriented penalties calls for renewed evaluation of the emergent practice of imposing significant economic punishment for minor crime convictions. Punishment-through-process and the burdens incident to repeated court appearances still plague defendants on misdemeanor dockets. But courts are now supplementing the pure process burdens with economic sanctions tied to the process, insisting that misdemeanor defendants pay much of the costs associated with the adjudication process plus hearty fines. Such processoriented economic sanctions include, just for example, probation oversight fees, tether fees, drug testing costs, police and prosecutor reimbursements, and many other costs and fines, as explained in detail below. This trend is most remarkable in jurisdictions outside of big cities where conviction rates are higher, and especially with respect to certain minor charges.

7 See Bernard Harcourt, Illusion of Order (Cambridge: Harvard University Press, 2001). In his important critique of "broken windows" or order maintenance policing, Harcourt argues that the benefits of these law enforcement strategies come from the increased surveillance offered by aggressive misdemeanor arrests and aggressive stop-and-frisk policies rather than from "normchanging." Harcourt at 10 -11. See also Ian Weinstein, "The Adjudication of Minor Offenses in New York City” (2004) 31 Fordham Urb. L.J. 1157 at 1175 -1176.

8 A criminal conviction can lead to deportation, the forfeiture of public of subsidized housing, the inability to get certain licenses and public contracts, and even the loss of the right to vote. See Margaret Colgate Love, "The Debt That Can Never Be Paid” (2006) 21 Fall Crim. Just. 16. 
In fact, in recent years, the increasing fines, costs, and other fees assessed in misdemeanor adjudication have become staggering. The total amounts assessed per conviction, often not obvious because assessed and accounted for in so many different forms, are out of reach for many of the defendants against whom they are assessed. That is, although each newly imposed fee is often viewed as a solitary cost, the cumulative impact of all of the economic obligations creates a significant problem for most defendants. Moreover, the ad hoc fashion with which these sanctions have developed has also stymied any comprehensive evaluation of the issue.

Meanwhile, courts have demonstrated an almost total disregard for the ability of the defendants to afford the amounts assessed, regularly requiring a defendant to pay immediately a sum that is simply impossible given the defendant's income. Yet these burdens are being borne by a segment of the population least likely to be able to bear them, as a majority of the misdemeanants are indigent. To make matters worse, criminal convictions, including misdemeanor convictions, necessarily diminish one's earning capacity and employment prospects, as well as one's eligibility for other social goods, such as professional licenses, some public and subsidized housing, and other public benefits. ${ }^{9}$

The precise costs of this development are hard to quantify with specificity, but they are likely significant. For starters, social welfare losses resulting from lost wages and income tax revenues, combined with the increased costs of new prosecutions when economic fines and other sanctions are not paid and the increased costs of public assistance for low-income defendants who lose their jobs, all have to be measured against the short-term increase in county revenues collected from economic sanctions. There is a larger problem as well: the courts' recent willingness to impose greater process-oriented economic sanctions for minor crimes cannot be easily justified by any of the traditionally understood theories of criminal punishment. That difficulty, coupled with the questionable social balance sheet resulting from the increased sanctions, casts serious doubts on this new practice.

\section{THE PRACTICE EXPLAINED}

"Punishment for minor crimes" does not mean "minor punishment." Though the latter is a less unwieldy term, it begs a central question-whether punishment for minor crimes is indeed minor punishment. To address that question, this Essay focuses on misdemeanors for which the punishment administered is economic in nature. Economic punishment in American jurisdictions is always discretionary. Judges levy fines and costs pursuant to statute, but the authorizing statutes provide few guidelines and enormous

9 Love, ibid. A recent study found that $60 \%$ of employers were unwilling to hire an applicant with a criminal record. See Alan Rosenthal and Marsha Weissman, "Sentencing for Dollars: The Financial Consequences of a Criminal Conviction" [working paper, February, 2007], Center for Community Alternatives, Justice Strategies. Ten states explicitly condition the right to vote on the full payment of the costs associated with a conviction. See Brennan Center for Justice, policy brief, "Restoring Voting Rights to People with Criminal Convictions,” online: Brennan Center for Justice $<$ http:// www.brennancenter.org/dynamic/subpages/download_file_38482.pdf>. 
discretion. The scope of discretion produces a wide variance in the norms applied by different jurisdictions, and even by different judges within the same jurisdiction. Even so, there is plainly an overall trend toward increasing the number and size of economic sanctions in misdemeanor punishment. Today, economic sanctions are used in all American jurisdictions: large and small, urban and rural.

This practice is especially important considering that the misdemeanor docket makes up a huge portion of the overall criminal docket in America. For instance, in 2004, the State of Michigan prosecuted roughly 66,000 felonies ${ }^{10}$ as against 825,000 misdemeanors. ${ }^{11}$ Misdemeanors thus accounted for about 82 percent of Michigan's total criminal docket in that representative year. Michigan is by no means an outlier.

The kinds of cases prosecuted on the misdemeanor docket are unsurprising: assaults without weapons or injuries, shoplifting, possession of marijuana, driving while intoxicated or with a suspended license, public disorder offenses, and an increasing number of traffic offenses. While most misdemeanors are punishable by some amount of jail time, that amount is generally small. ${ }^{12}$ That said, jail is not generally imposed, even when it is an available sentence. ${ }^{13}$

The misdemeanor docket is often described as largely a "poverty docket."14 All of the available data suggests that people in the criminal justice system have limited education, ${ }^{15}$ and limited employment histories and opportunities. ${ }^{16}$ Approximately $75 \%$ of defendants charged with misdemeanors are indigent and therefore entitled to court-appointed counsel. ${ }^{17}$ And the quality of representation provided by court-appointed counsel in most misdemeanor courts is typically very low. ${ }^{18}$ This is largely true for the felony docket as well,

10 U.S., National Center for State Courts, Examining the Work of State Courts, 2005 (2006); U.S., National Center for State Courts, State Court Caseload Statistics, 2005 (2006) .

11 Ibid.

12 In Michigan, for example, most misdemeanors are punishable by 93 days or fewer. There is a small set of misdemeanors which are punishable by up to one year.

13 For example, in three weeks of sentences imposed on one docket in Washtenaw County, Michigan, see section III, infra, a defendant was sentenced to jail only once, and in that case the jail sentence was coupled with economic sanctions. On the other hand, a number of cases on the docket concerned defendants who had been ordered to appear because they had failed to meet their economic sentence obligations, and in a handful of these cases, jail was imposed together with new economic sanctions.

14 Mandelbaum, supra note 6.

15 Rosenthal and Weissman, "Sentencing" supra note 9; see also New York State Dep't of Correctional Services, "Hub System: Profile of Inmate Population Under Custody on January 1, 2003."

16 Rosenthal and Weissman, supra note 9 at 6.

17 The U.S. Bureau of Justice Statistics reports that $80 \%$ of all felony-charged defendants are represented by assigned counsel. Caroline Wolf Harlow, "Defense Counsel in Criminal Cases," (2000) Bureau of Justice Statistics, Wash. D.C. And the percentage of black and Hispanic defendants with court-appointed counsel is higher than white defendants. According to the BJS website: "While $69 \%$ of white State prison inmates reported they had lawyers appointed by the court, $77 \%$ of blacks and $73 \%$ of Hispanics had publicly financed attorneys." Some studies put this number higher. See Peter Joy and Kevin McMunigal, "Client Autonomy and Choice of Counsel” (2006) 21 Fall Crim. Just. 57.

18 See Mary Sue Backus and Paul Marcus, "The Right to Counsel in Criminal Cases: A National Crises” (2006) 57 Hastings Law J. 1031 at 1034-1037. Much of the quality issues can be accounted 
but on the misdemeanor docket, people are charged with crimes for doing things such as stealing food or diapers or driving to work when they have not yet been able to pay an outstanding speeding ticket. In addition, like the rest of the criminal docket, minorities are disproportionately represented on the misdemeanor docket. ${ }^{19}$ Men are twice as likely to be charged as women. ${ }^{20}$

For defendants convicted of misdemeanors, economic sanctions come in many forms. Some of these sanctions, such as fines and costs, have a long history in criminal punishment, but many others are more recent innovations in fee collection. Courts now impose probation oversight fees, ${ }^{21}$ drug testing fees, ${ }^{22}$ tether fees in driving and sometimes also in non-driving drug or alcohol cases, ${ }^{23}$ recovery costs to the prosecutor, ${ }^{24}$ public defender, ${ }^{25}$ and police, ${ }^{26}$ in some jurisdictions application fees to be assigned a public defender, ${ }^{27}$ as well as the costs of various court-ordered programs. ${ }^{28}$ While most of these fees

for by the lack of funding which results in excessive caseloads for court-appointed counsel in many jurisdictions. See Norma Lefstein and Georia Vagenas, "Restraining Excessive Defender Caseloads: The ABA Ethics Committee Requires Action” Champion (30 December 2006) at 10.

19 See Kathleen Daly and Michael Tonry, "Gender, Race and Sentencing" (1997) 22 Crime \& Just. 201 at 201-203; Jerome G. Miller, "From Social Safety Net to Dragnet: African American Males in the Criminal Justice System” (1994) 51 Wash. \& Lee L. Rev. 479 at 483 (arrests for minor crimes disproportionately impact young African American men). In California, for example, misdemeanants are 39.8\% white, $60.2 \%$ minority. online: Office of Attorney General < http:// ag.ca.gov/cjsc/publications/candd/cd05/tabs/2005Table31.pdf >.

20 Daly and Tonry, ibid. at $201-203$. Again, in California, misdemeanants are $78.2 \%$ male, and $21.8 \%$ female. Ibid.

21 Probation oversight fees are either charged in monthly installments or as a lump-sum amount. In Washtenaw County, Michigan, monthly fees are $\$ 20$, and misdemeanor probation generally lasts from six months to a year. In other nearby counties they are significantly higher. For example, in Oakland County, Michigan, monthly fees are $\$ 50$. Notes of Interview with Anne Savickas, Probation Supervisor, Washtenaw County (April 2, 2007).

22 Defendants are often sentenced to consent to random drug and/or alcohol testing for which they pay the costs. In Washtenaw County oral and urine tests are charged at a rate of $\$ 20$ $\$ 25$ per test. They can be required as often as daily. If the defendant requests a confirmation of positive urine test results, that costs $\$ 50$. online:Washtenaw County Trial Court <http:// washtenawtrialcourt.org/community_corrections/program_fees $>$.

23 The county's corrections department administers the "alcohol tether" service for the courts. The service permits the agency to read the defendant's breath alcohol content any number of times a day, by requiring the defendants to record this content via a device attached to a land phone line. It is expensive. There is a $\$ 100$ enrollment fee and then a daily fee of either $\$ 10$ or $\$ 15$ dollars, and defendants must have a dedicated phone line for the tether. online: Washtenaw County Trial Court <http://washtenawtrialcourt.org/community_corrections/program_fees>. The tether can and usually is ordered for the entire time the defendant's case is pending, and often is continued through some or all of his or her sentence, which means that defendants pay these fees for many months.

24 Recovery costs to the county prosecutor are designed to offset the costs of prosecuting the case. In Washtenaw County the amount assessed is usually $\$ 100$.

25 Recovery costs to the public defender are assessed to offset its costs in representing the defendant.

26 Recovery costs to the police are assessed to offset costs arresting and charging the defendant.

27 Ronald F. Wright and Wayne A. Logan, "The Political Economy of Application Fees for Indigent Criminal Defense” (2006) 47 Wm. \& Mary L. Rev. 2045.

28 In alcohol and drug cases defendants are often sentenced to complete outpatient recovery programs, in domestic violence cases defendants are sentenced to complete anger management programs and in shoplifting cases, defendants are sentenced to complete theft offender programs. The costs of these vary but the range in Washtenaw County is from $\$ 100-500$ for alcohol and theft offender programs. Interview with Anne Savickas, Probation Supervisor, Washtenaw County, supra note 21. The domestic violence programs are more expensive. 
are imposed on the defendant as conditions of his or her sentence, some are imposed as conditions of his or her bond while the case is pending and are not refunded to defendants who are acquitted of their underlying charge. ${ }^{29}$ All of the economic sanctions in misdemeanor cases are for fixed amounts. To most of the individuals against whom they are assessed, the amounts are very significant, whether measured as a percentage of their weekly or monthly income, or by a broader look at their ability to pay, or by any other reasonable measure.

The increasing criminalization of traffic offenses accounts for part of the expansion in the misdemeanor docket and constitutes one important case study on the topic of economic sanctions. That is, most states have begun to impose onerous restrictions on driving privileges for the failure to pay traffic tickets. In Michigan, for example, a driver who fails to pay a speeding ticket on time will have his or her license administratively suspended. Drivers must then pay a fee of $\$ 125$ to $\$ 250$ to reinstate the license. ${ }^{30}$ This fee is of course added to the amount already due on the speeding ticket, plus any surcharge for late payment.

When a license is administratively suspended, a notice of the suspension is sent to the address on the driver's license which, especially for the transient population living in or at the margins of poverty, is often no longer correct. If the driver does not receive the notice, or receives it but does not respond, a court will issue a bench warrant. That bench warrant will require the driver's personal appearance in court and payment of the "bench warrant fee" in order to have the warrant vacated. ${ }^{31}$ In the meantime, if the driver is pulled over by the police for any reason, legal or illegal, and shows them his or her license, he or she will be charged with the crime of driving with a suspended license ("DWLS"). ${ }^{32}$ This charge is a misdemeanor, and carries an authorized sentence of up to $\$ 500$ and/or 93 days in jail for a first offense, and up to $\$ 1000$ and one year in jail for a second offense. ${ }^{33}$

As will be shown below, however, the authorized fine is only one of a number of economic obligations a defendant convicted of this offense will owe the court. This new misdemeanor is a strict liability statute, which means the prosecution will not have to prove any intent or knowledge on the part of the driver to convict him or her. This new criminal charge will require its own new round of court appearances, with corresponding fines, costs and other economic sanctions that also must be paid before the license can be reinstated. Once convicted, the state agency which issues (and suspends)

29 For example, many defendants are required to pay the costs of an alcohol tether while their case is pending. See supra note 23. And many jurisdictions, including Washtenaw and Wayne counties in Michigan, also require defendants released on bond in domestic violence cases to participate in a pre-trial supervision program. These programs, generally run by the probation department, mirror post-conviction supervision, including home visits and drug and alcohol testing. The defendants pay for these services just as they would post-sentence.

30 The charge for general reinstatement is $\$ 125$, for reinstatement for a drug crime the charge is $\$ 250$ and for reinstatement for minor in possession the charge is $\$ 250$; online: The Unofficial Guide to the DMV < http://www.dmv.org/mi-michigan/suspended-license.php>.

31 In Washtenaw County the "bench warrant fee" is usually $\$ 50$.

32 Mich.Comp.Laws.Ann \$257.904 (West Supp.2006).

33 Ibid. 
licenses imposes another fee, the "Driver Responsibility Fee" which requires that the defendant pay the agency $\$ 500$ a year for two years. ${ }^{34}$ The DWLS charge is the fastest growing charge on many state misdemeanor dockets. ${ }^{35}$

Defendants convicted of misdemeanors are often surprised by the sum total of the economic obligations imposed against them. There is nothing about the process that forewarns of the totality of the large penalties assessed, and it is not clear that even lawyers fully appreciate the entire range of economic sanctions imposed on their clients. ${ }^{36}$ Specific examples of the problem illustrate this best.

\section{ILLUSTRATION OF THE PROBLEM}

Consider the following sets of economic sanctions for three typical misdemeanor cases on one district court docket in Washtenaw County, Michigan, in 2006. ${ }^{37}$ By way of background, Washtenaw County is in relevant ways a typical American county with a typical misdemeanor docket. ${ }^{38}$ The defendants charged on the docket are representative of those charged in similar counties across the country, in the ways noted above.

For the purposes of this study, the sentences imposed on all of the cases sentenced by this court from November 30th through December 13th, 2006 were recorded. So were all on-the-record interactions between defendants and the court about defendants' abilities to make payments on the economic sanctions imposed. When interactions between defendants and their counsel were conducted out in the open, those were recorded as well. The specific misdemeanors described below were selected because they are representative with respect to economic sanctions imposed.

\section{A. Examples: Three Common Misdemeanors}

Defendants convicted of driving under the influence of alcohol (drunk driving $)^{39}$ on this docket, for example, were required to pay several fees, with only minor variations from case to case. The largest fee was $\$ 1040$ in fines and court costs, and this fee was assessed against all defendants. They were also often assessed a $\$ 100$ "recovery fee" for the Michigan State Police and a $\$ 100$ "recovery fee" for the Washtenaw County Prosecutor, both intended to offset

34 Online: State of Michigan < http://www.michigan.gov/driverresponsibility>.

35 In the State of Washington DWLS cases fill approximately one-third of the misdemeanor court dockets. John B. Mitchell and Kelly Kunsch, "Of Driver's Licenses and Debtor's Prison” (2005) 4 Seattle J. for Soc. Just. 439 at 443.

36 Rosenthal \& Weissman, "Sentencing", supra note 9 at 14.

37 The cases described in this section are all taken from the sentencing dockets of the 14th District Court on November 30th, December $6^{\text {th }}$, or December $13^{\text {th }}$, 2007. The sentences imposed on these dates were consistent with sentences imposed by the same court months earlier and later.

38 Washtenaw County is located in southeast Michigan, covering an area of 720 square miles. Its 27 cities, villages and townships are home to about 325,000 citizens in urban, suburban, and rural settings. Online: <http://www.ewashtenaw.org/about/index_html\#basics>. According to the county's website, $11.4 \%$ of families with children under 18 were living below the poverty line in the last 12 months, and $35.8 \%$ of families with children under 18 were headed by a female alone, with no husband present. Ibid.

39 Supra note 32 at $\$ 257.625$. 
the county costs of policing and prosecuting their crimes. All defendants convicted of this crime also had to pay the costs of their alcohol "tether." This sanction is required as a condition of bond and costs $\$ 100$ to enroll in the program and either $\$ 10$ or $\$ 15$ per day ${ }^{40}$ for the entire period of pre-trial release, and sometimes through part or all of a defendant's sentence.

The alcohol tether was used in every drunk driving case recorded. The county's corrections department administers the tether service for the courts. The service permits the agency to read the defendant's breath alcohol content any number of times a day by requiring the defendants to record this content via a device attached to a land phone line. The land phone line requirement is an added financial burden to many of the defendants who rely on calling card and pay phones for phone services and are required to install a land-line to comply with this bond condition.

There were additional costs as well. Defendants convicted of drunk driving were also required to complete a court-sponsored alcohol program, which cost another $\$ 250$ - $\$ 300 .{ }^{41}$ In addition, they were ordered to contribute to the cost of their own probation supervision at a rate of $\$ 20$ per month. ${ }^{42}$ And, like many other probationers, they were required to pay the cost of random drug and alcohol screens. ${ }^{43}$ The total court-bill for the misdemeanor conviction of driving under the influence of alcohol, then, assuming the defendant paid all ordered costs in full on time, and thus did not incur any additional fines or fees for late or non-payment, was approximately $\$ 3000$.

But the court bill is not the only bill offenders convicted of this charge will face. Once convicted of drunk driving, the state agency which issues licenses suspends the offender's license for six months, and it will cost the driver $\$ 125$ - \$250 to reinstate it. ${ }^{44}$ In addition, the agency will impose a "Driver's Responsibility Fee" on the offender which will cost the driver another $\$ 1000$ a year for two years. ${ }^{45}$ All told, in order for the defendant to complete payments to the court and to the agency for his drunk driving conviction would cost over $\$ 5000.46$

40 See supra note 23.

41 In Washtenaw County there are two choices, a ten week program which costs 25 dollars a week or an intensive weekend-long program which costs 300 dollars. Savickas, supra note 21.

42 Washtenaw County is not alone in charging defendants for their probation. In fact, jurisdictions across the country do this for probation and for parole supervision as well. For example, in 2002 the Suffolk County Probation Department, in Suffolk County, New York, collected \$1,165,242.71 in administrative fees from probationers. Of that, $\$ 981,722.71$ was for "supervision" fees, and $\$ 59,999$ was from drug testing fees, and $\$ 123,530.00$ was from fees charged for preparing presentence investigation reports. Rosenthal and Weissman, "Sentencing", supra note 9.

43 Charging defendants for their drug and alcohol screens is not a Washtenaw County innovation alone. See supra note 42. In Washtenaw County this cost the defendant $\$ 20-\$ 25$ per test. See supra note 22

44 See supra note 30.

45 See supra note 34.

46 Obviously driving under the influence is a serious crime, which should be punished. And while it might be the case that some of the offender charged with drunk driving were barely over the legal limit, there are still strong arguments which support harshly punishing them. The relevant question in this example is how to administer that punishment, not whether to administer it. 
Defendants convicted of driving with a suspended license $\mathrm{e}^{47}$ were treated uniformly as well, again with only minor variations. These defendants were sentenced to pay $\$ 710$ fines and costs. Some were also required to pay $\$ 75$ to serve in the "jail-work program." In the county's jail-work program offenders report to the county jail in the morning and are "admitted" for the day during which they perform work projects for the county, under the supervision of jail employees. At the end of the day they are "released," to return the next day if sentenced to more than a single day in the program. On top of that, some DWLS offenders were required to complete a "traffic safety program." A defendant facing this conviction would need approximately $\$ 1000$ before he or she could satisfy her court-ordered economic obligations. In these cases, the fines and fees imposed directly by the court were only part of the economic sanction, however. As explained earlier, these defendants also faced a separate set of costs assessed by the state agency which issues drivers' licenses to restore a license, including a reinstatement fee, which runs from $\$ 125$ - $\$ 250^{49}$, and a “Driver's Responsibility Fee," which will cost another $\$ 1000$ total. $^{50}$ All told, to comply with court and agency economic obligations, the defendant would owe at least $\$ 2000$ as a result of this charge.

Defendants convicted of shoplifting ${ }^{51}$ on this docket faced a similar set of economic sanctions. These defendants were generally sentenced to pay $\$ 765$ in fines and court costs. They were required to complete a theft offender treatment program which cost $\$ 100 .^{52}$ Like many of the other defendants, shoplifters were also sentenced to pay for their probationary supervision at a cost of $\$ 20$ per month and they were required to pay the costs of random drug screens, at the cost of approximately $\$ 20$ to $\$ 25$ per test. They were also required to complete 50 hours community service. A defendant convicted of this charge was facing a total of approximately $\$ 1500$, again assuming all obligations were paid in a timely way.

But the total size of the economic sanction imposed for each crime was not, itself, the most difficult aspect of the sanction for the defendants in question. The bigger problem was time. These economic sanctions are imposed essentially on a "pay or stay" basis. That is, the defendants convicted on this docket were given from (in most cases) a couple days to pay the fines and costs associated with each sentence to (in a few cases) a few weeks. For those failing to pay on time, which formally constituted a part of their sentences, the court issued a bench warrant. The bench warrant required defendants in violation of their economic sentences to appear in court and pay a "bench warrant fee" in order to have that warrant vacated and to be sentenced anew on the violation of the sentence or condition of probation. Here is the rub: These violation sentences almost always include more fines (and sometimes jail).

47 Supra note 32.

48 The cost of this program was not obvious from the sentencing docket, but is likely comparable to the theft offender and alcohol programs, which cost anywhere from $\$ 100$ to $\$ 300$.

49 See supra note 30.

50 See supra note 34.

51 Supra note 32 at $\$ 750.356$ (c)-(d) Shoplifting is otherwise known as "retail fraud."

52 See supra note 48. 
Table 1 summarizes the costs and fines assessed against misdemeanants for the mentioned crimes:

Table 1.

\begin{tabular}{|c|c|c|c|}
\hline & $\begin{array}{l}\text { Drunk } \\
\text { Driving }\end{array}$ & DLWS & Retail Fraud \\
\hline Fines and Costs & $\$ 1040$ & $\$ 710$ & $\$ 765$ \\
\hline $\begin{array}{l}\text { Recovery Costs to } \\
\text { police, prosecutor, } \\
\text { public defender }\end{array}$ & $\$ 100-\$ 300$ & $\mathrm{~N} / \mathrm{A}$ & $\mathrm{N} / \mathrm{A}$ \\
\hline Tether fees & $\begin{array}{l}\$ 100+\$ 10- \\
\$ 15 / \text { day }\end{array}$ & $\mathrm{N} / \mathrm{A}$ & $\mathrm{N} / \mathrm{A}$ \\
\hline Treatment Programs & $\$ 250-\$ 500$ & $\mathrm{~N} / \mathrm{A}$ & $\$ 100$ \\
\hline Probation Fees & $\$ 20 /$ mo. & $\mathrm{N} / \mathrm{A}$ & $\$ 20-50 /$ mo. \\
\hline Drug Screening & $\$ 25 /$ wk. & $\mathrm{N} / \mathrm{A}$ & $\$ 25 / \mathrm{wk}$ \\
\hline Traffic Safety Program & $\$ 100-\$ 300$ & $\$ 100-\$ 300$ & $\mathrm{~N} / \mathrm{A}$ \\
\hline $\begin{array}{l}\text { Driver's License } \\
\text { Reinstatement Fee }\end{array}$ & $\$ 125-250$ & $\$ 125-250$ & $\mathrm{~N} / \mathrm{A}$ \\
\hline $\begin{array}{l}\text { Driver's Responsibility } \\
\text { Fee }\end{array}$ & $\$ 2000$ & $\$ 1000$ & \\
\hline $\begin{array}{l}\text { Alcoholics Anonymous } \\
\text { Meetings }\end{array}$ & $\begin{array}{l}\$ 20 / \text { per } \\
\text { (between } 2 \text { and } \\
20 \text { given) }\end{array}$ & $\mathrm{N} / \mathrm{A}$ & $\mathrm{N} / \mathrm{A}$ \\
\hline Jail Work Program & $\$ 75 /$ day & $\$ 75 /$ day & $\mathrm{N} / \mathrm{A}$ \\
\hline \multirow[t]{2}{*}{ Community Service } & $\mathrm{N} / \mathrm{A}$ & $\mathrm{N} / \mathrm{A}$ & Up to 50 hours \\
\hline & ------------- & ------------- & ------------------- \\
\hline POSSIBLE TOTAL & a $\$ 5500$ & a $\$ 2200$ & @ $\$ 1615$ \\
\hline
\end{tabular}

\section{B. Individual Consequences}

Two things happen to those who cannot pay on time. More fines are assessed for their failure to pay, or for paying late, and, if misdemeanants still cannot find a way to pay, eventually they are incarcerated. In response to such consequences, it is not uncommon for defendants to promise the court their student loan money, ${ }^{53}$ their grandmother's Supplemental Security Income $[\mathrm{SSI}] \mathrm{check}^{54}$, or their father's minimum wage paycheck, ${ }^{55}$ all of which the court accepted.

This plays out in one of three general ways in the courtroom, on the occasion of defendants reporting to the court for their misdemeanor sentencing. One group of defendants "runs." That is, some defendants show

53 People v. Tirenda Mitchell-Mcganghy, $200114^{\text {th }}$ Dist. Ct. 05-0319. This case is from the same court but was adjudicated a year prior and handled by students at the University of Michigan's Clinical Law Program.

54 People v. Ronald Vanderkooy, $200614^{\text {th }}$ Dist. Ct. 06-358.

55 People v. Lisa Sorrell, $200614^{\text {th }}$ Dist. Ct. 06-2870. 
up in court for their sentencing only to be informed by their attorneys, often public defenders, that they will have to find a considerable sum of money to pay that day. Hoping to avoid the unavoidable, they simply leave the building before their case is called. There were a number of examples in the studied cases of defendants choosing this response. For example, Mr. Jermaine Moore, ${ }^{56}$ a black man who appeared to be in his twenties and qualified to be represented by the public defender, was present in the courthouse on the morning of his sentencing. But when he was told by his public defender that he needed more money or the judge would put him in jail, he disappeared. His public defender reported these facts to the court when his case was called, and as the judge issued a bench warrant for his arrest, he joked that "he's probably out dealing drugs in the parking lot." 57

A second group of defendants tries to reason with the judge about their ability to pay, and ultimately succumb to the judge's bullying in the face of all reason based on the financial evidence they presented. For example, Mr. Jon Tate, ${ }^{58}$ also a black male who appeared to be in his twenties and who was unrepresented by counsel, was being sentenced on his conviction for drunk driving. Mr. Tate showed up with $\$ 162$ and hoped to make arrangements to pay the balance. Mr. Tate owed a total of $\$ 1040$ in fines and court costs, $\$ 200$ in back probation fees, and $\$ 162$ arrearages on his tether. The tether would continue for another month, probation for another 12 months, and he still had to attend two Alcoholics Anonymous meetings a week, a limited outpatient program, and random alcohol screens at his expense. Tate asked for three weeks to pay the remainder of the fines and costs which were due. The judge took him into custody, and ordered him to find "anyone" who could get him all the money that day. Tate made some calls, and after remaining in custody for two hours reported that he had found someone who would pay all the money that day. The judge warned, "if it isn't paid today, I am issuing a bench warrant for your arrest." 59

Another example was Ms. Amy Butler, ${ }^{60}$ a white woman who appeared to be in her twenties and who qualified for court-appointed counsel, who was sentenced for her conviction for failing to report an accident. Ms. Butler owed $\$ 595$ in fines and costs and was $\$ 56$ in arrears on her tether. She started by asking for 60 days to pay, and then quickly moved to 30 days to try to counter to the judge's negative response. The judge ordered her to borrow the money and pay it all that day. She agreed, but there was no evidence that would lead any reasonable observer to believe she would be able to manage same-day payment.

Yet another example was Ms. Margaret Emerick, ${ }^{61}$ a white woman who appeared to be in her forties and who qualified for court-appointed counsel, who was being sentenced for her conviction for larceny. She owed $\$ 1420$ in fines and costs and $\$ 982$ in restitution. She still had to complete a theft

56 People v. Jermaine Moore, $200714^{\text {th }}$ Dist. Ct. 06-379.

57 Ibid.

58 People v. John Tate, $200614^{\text {th }}$ Dist. Ct. 06-2652.

59 Ibid.

60 People v. Amy Butler, $200614^{\text {th }}$ Dist. Ct. 06-2418.

61 People v. Margaret Emerick, case $200614^{\text {th }}$ Dist. Ct. 06-2222. 
offender program, which would cost her another $\$ 100$. Ms. Emerick showed up to court with $\$ 710$, and informed the judge that she had arranged with the prosecutor to pay the rest in monthly installments, who agreed. The judge refused to honor the agreement and ordered the whole amount due within two days.

Yet a third group of defendants makes a good faith effort to pay, but is taken into custody anyway. For example, Ms. Lisa Sorrell, ${ }^{62}$ a white woman in her twenties who qualified for court-appointed counsel, was sentenced for receiving and concealing stolen property. Ms. Sorrell owed a total of $\$ 1420$ in fines and court costs. She informed the judge that she was a single mother living with her own parents and not working because she had just gotten over a disabling injury. She arrived at court with $\$ 25$, and asked for a payment plan to pay off the balance. After a lengthy speech about personal responsibility, the judge took her into custody and told her that she had to find someone from whom she could borrow the whole amount if she wanted to be released. Hours later her father showed up and told the court that he could give the court his entire $\$ 250$ paycheck when he received it the next morning. The judge accepted this offer, and required the payment of the balance within one month.

Ms. Holly Lamon also fell into this category. ${ }^{63}$ Ms. Lamon, a white woman in her twenties, was sentenced for her conviction for drunk driving. Ms. Lamon owed $\$ 1040$ in fines and court costs, and $\$ 209$ in recovery costs to the police department and prosecutor. She had yet to complete the county's alcohol awareness program, which would cost another $\$ 250-\$ 300$, or to attend six Alcoholics Anonymous meetings. She came to court with $\$ 600$ and asked to pay the balance within two weeks due to other financial obligations. The judge responded that her immediate payment was a "matter of priorities" and, considering hers not to be in order, took her into custody.

These examples illustrate pleas that make it into the court record. It is not difficult to imagine similar stories that do not get aired in open court. Not every offender has funds within his or her reach to misallocate - a father with a minimum wage paycheck coming tomorrow, or a grandmother with an SSI check coming Friday, or a Pell grant expected next week -and some are forced instead to participate in the illegal economy to meet the terms of their economic sentence or to fail to meet them.

Almost certainly all of these examples are generalizable. For a number or reasons, pay-or-stay economic sanctions are on the rise in jurisdictions across the country. ${ }^{64}$ Often the driving impetus for increased economic sanctions is as simple as counties' needs for revenue. Relatedly, jail overcrowding (and counties' reluctance to pay for more jails) is another part of the likely explanation. Add to these explanations a growing national stomach for stricter sentencing and, on top of that, changed views over the past decade towards the poor generally. In post-welfare America, the division of the "deserving" and the "undeserving" poor, also known as the "working" and the "nonworking" poor, has become a comfortable and palatable basis for making

62 People v. Lisa Sorrell, supra note 55.

63 People v. Holly Lamon, case $200614^{\text {th }}$ Dist. T. 06-2648.

64 See Rosenthal \& Weissman, "Sentencing”, supra note 9 at 13; Ronald F. Wright and Wayne A. Logan, supra note 27 at 2046; John B. Mitchell and Kelly Kunsch, supra note 35. 
policy distinctions. ${ }^{65}$ This is an intelligible, if unfortunate, line for policymakers to draw.

But the larger social consequences of this phenomenon warrant more investigation. On the one hand, it is worth considering with an open mind possible justifications for this type of punishment. That is, as the state moves from spending money on criminal punishment to collecting money from criminal punishment, one might hope or expect that the practice finds justification in some more general theory of criminal punishment. ${ }^{66}$ Even if revenue-collection, rather than some more general theory of punishment, motivates the practice, at least some theory might justify it nevertheless. At the same time, any adverse and especially unintended social consequences of greater economic sanctions also warrant careful analysis too, in order to understand just how much weight any justification of the practice must carry.

\section{PURPOSES OF CRIMINAL PUNISHMENT}

Utilitarian and retributive justifications animate criminal punishment. And indeed, criminal punishment often is thought to be justified in part by both. ${ }^{67}$ Retribution is straightforward: If the defendant deserves to be punished, we have a duty to punish him. His moral desert is a sufficient reason for punishing him. No additional reason for punishing the defendant does any work for a retributivist. To a retributivist, other positive effects of punishment - safety for a community, deterrence for individuals or society - are irrelevant to the justification for punishment. These benefits might be considered fortunate side-effects, but that is all they are. While retributivists are not committed to any particular punishment system, they are committed to the idea that the punishment must "fit" the crime. And while retributivists might not all agree that an eye be paid for an eye, they would agree with the more general proposition that punishment be measured to match desert. ${ }^{68}$

Utilitarian theorists bundle various benefits of punishment in arguing that punishment is generally justified. Among the benefits most emphasized by utilitarian punishment theorists are specific deterrence, general deterrence, incapacitation and rehabilitation. ${ }^{69}$ Each of these does some positive social work justifying criminal punishment, and utilitarian theorists differ as to the

65 See Juliet Brodie, "Post-Welfare Lawyering: Clinical Education and a New Poverty Law Agenda" (2006) 20 Wash. U. J. of L. and Policy 201 at 219.

66 Justice Scalia has expressed this concern: "Imprisonment, corporal punishment, and even capital punishment cost a State money; fines are a source of revenue. As we have recognized in the context of other constitutional provisions, it makes sense to scrutinize governmental action more closely when the State stands to benefit." Harmelin v. Michigan, 501 U.S. 957at 979 (n.9 1991).

67 See generally Kenworthey Bilz \& John M. Darley, "What's wrong with the Harmless Theories of Punishment,” (2004) 79 Chi.-Kent L. Rev. 1215 (discussing consequentialism versus retributivism).

68 Michael S. Moore, "The Moral Worth of Retribution," in Ferdinand Schoeman, ed., Responsibility, Character, and the Emotions: New Essays in Moral Psychology (Cambridge: Cambridge University Press, 1987) at $179-182$.

69 Rehabilitation was a very low priority, of a priority at all, among policy-makers and theorists in the final decades of the last century, but has come back into favor in recent years. See generally, Edward L. Rubin, (2001) 19 Law \& Ineq. 343. 
value of each. Utilitarian theories of punishment have driven most American punishment policy and American jurisprudence for decades.

Many theorists, as well as most policy-makers, are compelled by both utilitarian and retributive theories of punishment, hoping to achieve both retributive and deterrent goals in fashioning criminal punishments. Having said that, in the context of minor crimes, deterrence and reform are featured above incapacitation, itself a familiar and central goal of criminal punishment. This is true because minor crimes by their nature are not those for which incapacitating wrongdoers is thought to be appropriate. First, and almost tautologically, minor offenses do not injure society enough to warrant divesting those convicted of their liberty, or taking them out of productive society. Second, the substantial costs of incapacitation are not thought to be worth it for those convicted of only minor crimes.

Whatever the specific purposes and justifications of criminal punishment, there is also general consensus that specific forms of punishment must be fairly applied. That is, sentences must be perceived as fair and proportionate to the wrong done. Punishments administered must also be broadly applicable and enforceable. In other words, punishment must not only advance theoretically justified goals, but it must be practically administered in a way that preserves rather than jeopardizes its justification. Thus the Federal and State Constitutions require that punishment be proportional, and not cruel and unusual. ${ }^{70}$ While these constitutional limits leave room for many different sentencing options, they constitutionalize norms of proportionality and evenhandedness.

While much commentary considers the application of traditional theories of punishment to major penalties, especially in the context of the death penalty and long-term incarceration, ${ }^{71}$ these theories have not been explored in connection with economic sanctions for minor crime. Thus, policy discussion surrounding sanctions for minor crime tend to focus solely on state and county revenue collection, not on theories of punishment, ${ }^{72}$ and they leave open important questions about the fit between such theories and the emergent sanctioning practice described.

It is not difficult to imagine what connections policy-makers might make, if required to do so. At first glance, substantial economic sanctions arguably further both retributive and utilitarian goals. Retribution is served by any system of punishment, including economic sanctions. Further, economic sanctions are directly compensatory: The offender pays his debt to society not metaphorically but literally. Similarly, economic sanctions appear to serve utilitarian goals of general and specific deterrence, discouraging similar conduct by (again literally) raising the costs of breaking the law. In other words, the deterrent effects of charging money for breaking the law could certainly be argued by policy-makers interested in raising the cost of crime to offenders.

70 See infra note 81.

71 Sunstein and Vermeule, supra note 2.

72 See e.g. "Jail Savings Shouldn't Trump Public Safety Yet Cumberland County Ought to Look for Ways to Cut the Cost of Handling Minor Crimes" Portland Press Herald (9 February 2007). 
Incapacitation, on the other hand, seems not well served by economic sanctions, again at least at first glance. By fining someone instead of jailing them, you are not incapacitating them in the traditional understanding of that term. But only at first glance: In practical terms, economic sanctions can in fact render someone incapacitated. While perhaps not exactly incapable of (re)committing the crime, many convicted misdemeanants become incapacitated in the sense that they are no longer able to function as productive members of society as a result of the fines and fees they owe to the court. They are "removed" from society in the sense that the impossible is asked of them, and then they are punished again when they cannot deliver the impossible.

This is so because of the haphazard way in which economic sanctions have evolved. New costs for the various parts of a defendant's sentence are added without any clear view of the sum total the defendant ends up owing with each conviction nor of the realistic probability that he or she can pay this obligation. Without any comprehensive understanding of the various fees, fines, and other costs imposed on a criminal defendant, then, the criminal justice system's ability to serve traditional goals of punishment is lost in the application. The following section explains.

\section{THE ADVERSE SOCIAL CONSEQUENCES OF ECONOMIC INCARCERATION}

None of the traditional theories of punishment easily vindicates increased reliance on economic sanctions for minor crimes when the phenomenon is considered on the ground. As noted, the economic punishments assessed are often too severe for most defendants to be appealing to most retributivists. Because they are not well calibrated, it is hard to imagine that most retributivists would find them satisfying. Again, retribution works as a justification for punishment only to the extent that punishments are proportional to desert. The moral culpability of the offender requires that he or she be punished, but only as far as is deserved. With the sanctions described above, most people pay a lot more than an eye for the eye. Misdemeanor sanctions often instead resemble an ad hoc occasion for excessive county taxation.

Deterrence is more complicated. To the extent the new system deters, which to some extent it must, it may be justified on that ground. Once it is understood that minor crimes bring substantial penalties, presumably those who understand as much will be less likely to engage in criminal behavior. One can reasonably quarrel with the size of any such deterrent effect, especially given the socio-economic class of many misdemeanants and their likely awareness of and response to the magnitude of sanctions. But the effect is probably not zero.

At the same time, however, pay-or-stay economic sanctions can lead to some perverse deterrence results by encouraging new illicit behavior. That is, in contrast to spending excessive time in jail-where it is difficult to repeat a crime-too much economic punishment can directly inspire wrongdoing among convicted misdemeanants struggling to comply with their out-ofreach economic obligations. By setting people up to fail to meet these court- 
ordered economic obligations, the system is asking them to do whatever it takes, even if whatever it takes is selling drugs in the parking lot. To the extent this happens, any limited deterrence value gained from punishing minor crimes severely may be undermined by encouraging the commission of other crimes or undesirable behavior. To put it one way, the ex ante deterrence benefits of expanded economic sanctions have to be balanced against the ex post deterrence costs.

The regress that many poor defendants experience upon being convicted of driving with a suspended license is an acute example. Once a defendant loses her valid license and is facing literally over two thousand dollars in court and administrative costs to get it reinstated, it is nearly impossible not to reoffend. In Michigan (home of the automobile), public transportation simply will not get most people to most jobs, the place where they can legally earn the income to attempt to get their licenses back. Poor people who end up convicted of this charge re-offend over and over again, and these people are sometimes caught. Each time they are caught, the fines and costs mushroom. ${ }^{73}$

In addition, the lack of any predictable link between the sanctions applied and the behavior to be deterred in this context may also undermine the deterrence yields of economic sanctions. Finding family members who will turn over their minimum wage paychecks, making whatever sacrifices that entails, to satisfy one's court-ordered economic obligations is not obviously linked to the nature of any particular offense. Rather, the punishment seems incidental and almost accidental. Put differently, increased economic sanctions may accomplish some specific deterrence, but little general deterrence. In any event, whatever deterrence benefits there are must be weighed against the shortcomings of this practice. Again, it is not a justification to be able to point to benefits alone. The policy question concerns the net consequences of the practice.

There are reasons to doubt that there are netbenefits. For starters, there is no question that there are more cases on courts' dockets as a result of defendants failing to pay their economic penalties on time. These inflated prosecution costs parallel the increasing costs of the process for the defendants, both in terms of additional dollars in the new fines and fees and of lost time. Increased process for defendants has been shown to have real economic costs, most commonly in the form of lost wages and jobs. ${ }^{74}$ Lost jobs lead, of course, to increased public assistance costs and reduced revenue collection in the form of income taxes. And, as previously shown, the class of people paying these collateral costs are the least able to do so. Already struggling with the effects of the criminal conviction itself on employment prospects, defendants also quickly learn that the inability to satisfy court-ordered financial obligations is recorded on a credit report, ${ }^{75}$ making economic progress nearly impossible. In a growing number of states, an unpaid court-ordered economic obligation will also prevent the defendant from voting. ${ }^{76}$

In addition, there is no question that this practice results in the

73 See Mitchell and Kunsch, supra note 35.

74 Feeley, supra note 5.

75 Rosenthal and Weissman, supra note 9 at 8.

76 Brennan Center policy brief, supra note 9. 
misallocation of other sources of government money and family money for some defendants to pay their economic sanctions. In just a few examples from one courthouse on just a few dockets, defendants were applying student loan grants, relatives' social security checks, and a father's minimum wage paycheck to satisfy their judgments. All of this undermines the integrity of the criminal justice system.

To recast the critique in more general terms, the practice of imposing economic sanctions at a level impossible for most defendants to succeed is not a defensible way to run a legal system. The practice is not based on clear rules, given the haphazard way in which the various fines and costs have evolved, and given the fact that the various costs are not generally understood by the participants going into sentencing. At the same time, there is no overall accounting done by any of the players in the system which puts defendants on notice of the sum total they will likely owe. Because not all lawyers fully anticipate the many pieces of these punishments, they do not do a very good job advising their clients about them. Defendants certainly are often surprised at the time of their sentence when the court reads off the panoply of costs they owe almost immediately. ${ }^{77}$

Because there is no obvious link between the crime and the economic punishment, the practice is, for that separate reason, not fair. A criminal defendant should have the potential to complete his sentence. But the system described above keeps individuals ensnared in it. The practice therefore undermines one aspiration of the legal system, which is an independent strike against it. If it served some instrumental purpose well, that might redeem the practice somewhat, but it does not. So there are many reasons to worry.

Another perverse result of this system-a very common yet underappreciated result - is that convicted offenders often prefer incarceration over economic sanctions. This stands the usual or assumed hierarchy of criminal punishment on its head. The non-poor consider jail time to be worse than fines or fees. But because incarceration is not a pure impossibility, as finding thousands of dollars may be, many indigent defendants do not share this view.

For example, in one recent case students of the University of Michigan Clinical Law Program represented a young woman on a shoplifting charge. ${ }^{78}$ She was nine months pregnant at the time of sentencing, and had a two year old and a three year old. She received social security disability (SSD) payments each month for her psychological disabilities. She had no other income, and there were no other adults in her household. She was accused of, and pled guilty to, stealing diapers from a Target store. Her fines and costs were the standard amount, totaling approximately $\$ 1000$. Paying these would consume two months of her SSD income leaving her with nothing left for food, rent or other basic needs.

This client told her student attorneys explicitly that she wanted to go to jail instead of pay the fines. She rightly assumed that she would be sentenced to

77 Of course, for DWLS in particular it can also often be shown that the defendant was also not aware that he or she was committing a crime.

78 I supervised them on the case. 
no more than 30 days. ${ }^{79}$ For her, this choice was entirely rational. She believed she could do the time, even if it meant having her next baby in jail, but she knew she could not pay the fine. It was an "unserveable" sentence for her. ${ }^{80}$ Compare this to the typical white collar criminal, eager to pay any amount to stay out of jail. If you have the means, paying is easy, and the stigma of jail is great. Economic sanctions are different than jail in this important way; any defendant can do time, but only some defendants can pay to avoid it.

In this light, high economic sanctions for minor crimes more clearly resemble incapacitation. The economic sanctions described above often do "incapacitate," just not in the way that term is commonly used in criminal punishment. They do not incapacitate offenders from committing additional criminal acts. In fact, the very opposite might be true, as just observed. But economic sanctions incapacitate not just people who struggle to pay them illegally, but also people who struggle to pay them legally, and with lots of collateral costs. In fact they often incapacitate entire families.

These ironies and defects notwithstanding, the problem with excessive reliance on economic sanctions for misdemeanors is not one susceptible to any easy constitutional fix. Eighth amendment jurisprudence will not reach economic sanctions. While it is clear that the disparate punitive impact of the fixed sum sanctions among offender groups distorts the principle of proportionality in sentencing, all of the proportionality doctrine concerns long prison sentences for seemingly minor crime, and even then it is generally not held to prohibit those long sentences..$^{81}$ Equal protection arguments might be the most likely to succeed. There is authority for the proposition that a court cannot incarcerate someone who cannot pay. ${ }^{82}$ But there is no authority yet for the proposition that a court cannot coerce people to make their grandmothers or parents give up their monthly fixed income, or worse - functionally requiring them to participate in the illegal economy - to satisfy the court's sanctions.

\section{THREE OBJECTIONS (AND REPLIES)}

One fair response to the above critique invokes the potential upside in

79 This was a great teaching opportunity and one of the clear benefits of clinical legal education. For the well-educated, well-off law students, this "choice" was incomprehensible. They worried she must be unfit to care for her kids if she was willing to leave them to go to jail and to give birth in jail.

80 People v. Tirenda Mitchell-McGaughy, supra note 53.

81 See e.g,. Ewing v. California, 538 U.S. 11 (2003), in which the Supreme Court held that California's "three-strikes law," under which Gary Ewing was sentenced to 25 years to life for stealing golf clubs did not violate the Eighth Amendment principle of proportionality. But see Solem v. Helm, 463 U.S. 277, 279 (1983), in which the Court held that the Eighth Amendment prohibited the sentence of life without the possibility of parole for writing a bad check.

82 In Tate v. Short, 401 U.S 395, 399 (1971), the Supreme Court held that imprisoning an indigent solely because he is unable to pay a fine contravenes the equal protection clause by discriminating based upon economic status. In Akridge v. Crow, 903 So.2d 346 (2005) the Florida Court of Appeals held that a county program that incarcerated indigent defendants for failure to pay fines and costs violated equal protection. Even so, this happens all the time in the lower criminal courts, usually because most defendants are not represented by counsel at hearings on violations of probation or sentence violations. 
revenue collection and the expense saved by avoiding jail overcrowding and incarceration. That is, it could well be argued that the financial benefits to the state or county through increase in revenues, together with the avoided costs of operating local jails, justifies broader and deeper economic sanctions as punishment for minor crimes. While increasing revenues and avoided expenditures might well be justifiable goals, neither is a justification for punishing someone in the first instance. To the extent they are justifiable goals, these goals are realized, if at all, only if the increased revenues exceed the sum total of the increased costs generated by more prosecution, the costs of more public assistance, and the reduction in tax collection. The question of how these varying social costs net out does not have an obvious answer, but since many of these defendants end up in jail when they ultimately cannot pay, economic sanctions might well create rather than save costs.

Part of the trouble here is that the revenues from higher economic sanctions flow only to the county, whereas the costs created by the same system are borne by the county (as a result of increased prosecutions), by the state government (as a result of increased social welfare expenditures), and also by the federal government (as a result of increased social welfare expenditures and decreased tax revenues from misdemeanants who lose their jobs). Because counties do not bear the full costs of their decisions to rely on economic sanctions, as they externalize some of those costs on higher levels of government, there is no reason to believe that counties make socially appropriate decisions.

An alternative defense of the system of increased economic sanctions is that there is some social value in requiring that transgressors contribute to the cost of processing their transgressions. Insofar as economic sanctions are meant to cover the costs of running the criminal justice system, those who require the operation of the system should bear some of its costs, even if this entails some undesirable side-effects. This defense has some merit, but it certainly does not end debate. While there may be some benefit to having transgressors contribute to the costs of operating a criminal justice system, that is true only to the extent that the assessment of those costs is calibrated to take into account both the actual costs of operating the criminal justice system and the misdemeanants' ability to pay those costs. Whether evaluated relative to the seriousness of their crimes, the costs of prosecuting their crimes, or their ability to pay, misdemeanor defendants are punished disproportionately relative to other criminal defendants. This observation argues not for scrapping economic sanctions all together, but for finding a way to make them rational. This concept raises a final anticipated objection.

It would also be reasonable to argue that the above critique has not shown that the system is wholly flawed, just that it is too crude. Economic punishments could be recalibrated to fit the crime and the criminal, and then the objections raised here would be mooted. Relatedly, in the absence of an alternative proposal for improving the current system of economic punishment, any $\ldots . . \ldots$ scheme must be judged against its alternatives, and critiques that do not 
take into account any comparative analysis are not very powerful. ${ }^{83}$ Certainly economic punishment should not be categorically excluded from the menu of available punishment choices. There are examples both from history and from other cultures which show this to be correct, as follows.

\section{ALTERNATIVES: RATIONAL MINOR CRIME PUNISHMENT}

In the late 1980s the borough of Staten Island in New York City piloted a project based on what is known as the "European day-fine." In Northern Europe, the fine is the primary non-custodial penalty in criminal cases, not only for misdemeanors but also low-level felonies. The day-fine systematically links the fine imposed to the offender's ability to pay. Staten Island used the West German and Swedish day-fine procedures to model its pilot project. It met with success. ${ }^{84}$

The system for administering this rational economic sanction was not complicated: Each offense was assigned a number of day-fine "units," ranging from a low of five units for the most minor offenses to a high of 120 units for the most severe. ${ }^{85}$ In addition, each offense was assigned both a "discount" and a "premium" number of units to give the court additional flexibility and to encourage judicial discretion in accounting for the mitigating and aggravating circumstances of individual cases. The value of the day-fine unit was then set in direct relation to the offender's economic means. The specific value of the day-fine unit for an offender was her daily net income, adjusted as necessary for basic personal needs and family responsibilities. ${ }^{86}$ Because this information was regularly collected at the arraignment stage for purposes of assigning counsel and making bail determinations, there was no additional burden placed on the court to arrive at a fair day-fine unit. In addition to particularized information about the day-fine unit value assigned to each person, the court also instituted particularized, and realistic, payment plans. The installment plans had short time frames and were set in relation to the offenders' payment patterns (their payments were due the first work-day after payday, for example). For low-income defendants, or those on public assistance, the formula mimicked that used by public assistance agencies when recouping overpayments made to clients. In New York City, the rate for withholding in welfare overpayment cases was ten percent of the public assistance grant, and therefore that was percentage used to calculate the

83 See Dan Kahan, "What do Alternative Sanctions Mean" (1996) 63 U. Chi. L. Rev. 591. Arguing in favor of shaming punishments, Kahan asserts that the value of shaming must be compared with the punishment that it is replacing; criticizing shaming punishments in a vacuum of no punishment is empty. Incidentally, in 1996 when Kahan published this piece, he criticized fines as legitimate punishment because, he said, society doesn't accept them as true punishment because offenders are viewed as "paying their way out" of punishment. Ibid at 620-623.

84 Judith Greene, The Staten Island Day-Fine Experiment (1990) [Unpublished, archived at Vera Institute of Justice]. See also U.S. Bureau of Justice Assistance, How to Use Structured Fines (Day-Fines) as an Intermediate Sanction (1996). 
amount of monthly fine payment for low-income offenders. ${ }^{87}$

Published reports indicate that the program was a success. Apparently judges found it easy enough to administer, as it was used in $73 \%$ of all fine cases during the first year of the pilot. It was clear, too, that judges used the program properly to differentiate among offenders of different means, as there was great dispersion of fine amounts within the ranges permitted for each offense. Perhaps most importantly, the high number of offenders who completed their payments is the greatest measure of the program's success. ${ }^{88}$

If it worked in Staten Island, with its busy urban docket, it seems transferable to just about any jurisdiction. A jurisdiction interested in adopting a day-fine system would be able to do so without adding significant infrastructure, if any at all. Courts in every American jurisdiction already collect enough basic economic information from the defendants who qualify for court appointed counsel, and some collect this information from every defendant, at arraignment or shortly thereafter. Most jurisdictions have an agency or service which conducts this process. Depending on the specific information collected, the jurisdiction might already have the basis for determining the day-fine amount for each offender if convicted. Assigning units to offenses is a one-time, very short-term project.

However, this program assumes that economic sanctions are appropriate in the first instance, and this might not be a correct assumption for some of the cases on the misdemeanor docket. For example, the bootstrapping practice of criminalizing driving with a suspended license when the reason for the suspension was a failure to pay a ticket, and then fining again for the new criminal charge seems counterproductive. This particular charge should not carry an economic sanction at all. If much of the crime control benefits from policing misdemeanors are achieved from the initial arrest and the ensuing significant burdens of appearing in court on this crime (as Feeley showed), a fine at the end of the case accomplishes little. This fact, together with the risk for economic costs to the state when defendants find themselves unable to climb out of a financial hole such as this one, argues for non-economic sanctions for this particular offense.

In addition to calibrating fines to match the individual offenders, sanctions should be calibrated to match the individual charge for which they are imposed. Sometimes little or no sanction, apart from the stigma of a criminal conviction and the considerable resulting collateral consequences of that-lost employment opportunities, immigration status, public housing and licensing opportunities-should be imposed. In fact carrots, rather than sticks, might better serve the goals of punishment for some offenses, as in the case of DWLS. Courts could cleverly but realistically incentivize the possibility of coming out of the case without a conviction: If the defendant comes back to court with proof that his license has been reinstated by the agency within some reasonable period of time, the court would dismiss the DWLS charge. If the goal of criminalizing DWLS is to be certain to get the attention of the offender who is driving without the state's authority, this 
approach would be well served by such a system. The court's jurisdiction, and threat of punishment, would serve the attention-getting goal. The chance for the defendant to avoid a criminal conviction and its costs, as well as to avoid paying an insurmountable sum to the court and the state agency, would underscore that goal and promote socially desirable behavior.

Additionally, particularized sentencing in the context of economic sanctions will better serve traditional punishment goals. Asking people to repay their debt at a level determined to be difficult but, crucially, not impossible will square with traditional understandings of retribution. When economic sanctions are not achievable-when in practice they amount to a form of economic incarceration-it is impossible for people to take them seriously, and therefore to be appropriately deterred by them. Sanctions which people can pay, even with difficultly, will better advance deterrence goals. Finally, squaring economic sanctions with the general goals of punishment will also improve the legitimacy of the criminal justice system generally, and not just for those directly involved.

\section{CONCLUSION}

The current American practice of assessing fixed-sum fines, fees, and program and supervision costs in punishing minor crime is bad policy and undermines the integrity of the criminal justice system. Economic sanctions are not like other sanctions; they are potentially more disproportionate than any other sanction and therefore should be used carefully. Moreover, the group of offenders burdened with them is exactly that least capable of bearing the burden, an important fact against which reliance on economic sanctions should be evaluated. The increasing criminalization of "status offenses" as in the case of the failure to pay a speeding ticket, one of the associated costs of driving, should inspire even more caution towards economic penalties, as should the often hollow promise of the right to counsel in misdemeanor prosecutions. As American jurisdictions seem increasingly quick to embrace economic sanctions for misdemeanants, with an apparent single-minded focus on revenue collection, scholars and policy-makers should encourage more careful consideration. 